[Agr. Biol. Chem., Vol. 34, No. 5, p. 753 759, 1970]

\title{
Studies on Alkaloids of Streptomyces
}

\section{Part II. Pharmacological Activity and Isolation of Nigrifactin and Taxonomical Studies of Streptomyces Strain No. FFD-101}

\author{
By Tadashi Terashima, Yoshiko Kuroda and Yasuyuki Kaneko \\ Department of Agricultural Chemistry, Nagoya University, Nagoya \\ Received September 18, 1969
}

\begin{abstract}
In the course of screening research on alkaloids among metabolites of microorganisms, Streptomyces strain No. FFD-101 which was isolated from a soil sample collected in Bankok of Thailand, was found to produce a new alkaloid, nigrifactin both in its culture filtrate and mycelium. This alkaloid possessed strong inhibitory activity against histamine and caused a transient fall of blood pressure. From the results of taxonomical study on the strain No. FFD-101, it was found that this is a variant of Streptomyces nigrifaciens, to which the name, Stroptomyces nigrifaciens var. FFD-101 was proposed. Examination of the alkaloid productivity with media in various compositions indicated that the medium containing glycerol $3 \%$ as carbon source and casamino acid $0.35 \%$ as nitrogen source was most suitable for the production.
\end{abstract}

In the previous paper ${ }^{11}$ of this series, we reported that Streptomyces strain No. FFD101 which was isolated from a soil sample collected in Bankok of Thailand, was found to produce an alkaloid in its culture filtrate. Furthermore this alkaloid hydrochloride possesses a strong inhibitory activity against histamine and causes a transient drop of blood pressure. In the course of further investigations on alkaloids of Streptomyces, we have succeeded in isolating a new alkaloid, which we named nigrifactin, from the culture filtrate and mycelium of strain No. FFD-101. The present paper deals with the pharmacological activity and isolation of nigrifactin and taxonomical studies of the strain No. FFD101.

\section{MATERIALS AND METHODS}

Taxonomical study. Streptomyces strain No. FFD-101

1) T. Terashima, Y. Kuroda and Y. Kaneko, Agr. Biol. Chem., 34, 747 (1969).

2) H. Nishimura and K. Tawara, J. Antibiotics, 10A, 82 (1957). was cultivated on each medium conventionally being used for the classification of Streptomyces at $27^{\circ} \mathrm{C}$ and/or $37^{\circ} \mathrm{C}$ and observed during a period of four weeks for the changes in growth, aerial hyphae and soluble pigment. The morphological properties of the strain were observed on organic media such as potato-glucose agar (2\% glucose, $1.5 \%$ agar in boiled extract of $500 \mathrm{~g}$ potato with 1 liter tap water) and Bennett's agar with agar-cylinder culture method. ${ }^{21}$ The structure of spore was observed under electron microscope. Utilization of carbon sources was determined by cultivation on Pridham and Gottlieb's ${ }^{31}$ medium which contain $1 \%$ of various carbon compounds.

Detection of pharmacological activity. The crystalline picrate of the alkaloid was dissolved in $1 \mathrm{~N} \mathrm{NaOH}$ solution and extracted with chloroform. The chloroform layer was extracted with $0.1 \mathrm{~N} \mathrm{HCl}$ solution and then the acidic solution was extracted with chloroform until free picric acid was perfectly removed. The aqueous solution of the alkaloid hydrochloride thus prepared from the picrate was neutralized to $\mathrm{pH} 6 \sim 7$ by using Amberlite IR-4B and employed for the

3) T.G. Pridham, C.W. Hesseltine and D. Gottlieb, J. Bacteriol., 56, 107 (1948). 
following pharmacological test. The pharmacological actions of the alkaloid on the serosa of the small intestine in vitro were observed with Magnus method. Choline, atropine, adrenaline, histamine and noradrenaline were used as stimulants at the final concentration of $5 \times 10^{-5}, 1 \times 10^{-5}, 1 \times 10^{-5}, 6 \times 10^{-6}$ and $1 \times 10^{-5} \mathrm{M}$, respectively. The rabbits were anesthetized with $1.0 \mathrm{~g} / \mathrm{kg}$ (intraperitoneal injection) of urethan. The mean blood pressure of the left carotid artery was recorded on a smoked paper via an arterial cannula and a mercury manometer. Spontaneous respiration was recorded on a smoked paper by means of rubber tambour connected to a tracheal cannula, simultaneously with the arterial blood pressure. The alkaloid was injected into the vein.

Cultural condition of the alkaloid productivity on various compositions of media. Examination of the alkaloid productivity on various compositions of media was carried out using basal medium as shown in Table I.

Table I. Composition of Basal Medium

\begin{tabular}{ll}
\hline Carbon sources $^{a l}$ & $30 \mathrm{~g} /$ liter \\
Nitrogen sources $^{a}$ l & 3.5 \\
$\mathrm{~K}_{2} \mathrm{HPO}_{4}$ & 1.0 \\
$\mathrm{KCl}$ & 0.5 \\
$\mathrm{MgSO}_{4} \cdot 7 \mathrm{H}_{2} \mathrm{O}$ & 0.5 \\
$\mathrm{FeSO}_{4} \cdot 7 \mathrm{H}_{2} \mathrm{O}$ & $0.01 \mathrm{pH} 7.0$ \\
\hline
\end{tabular}

a) Carbon and nitrogen sources employed for this experiment were listed in Table V.

The strain grown in $2 \%$ glucose-potato agar slant was transfered into test tubes containing $10 \mathrm{ml}$ of the each medium described above and incubated for 2 days at $30^{\circ} \mathrm{C}$. Then, $10 \mathrm{ml}$ of this culture broth was transfered into $500 \mathrm{ml}$ shaking flasks containing 100 $\mathrm{ml}$ of the same medium. The fermentation was carried out at $30^{\circ} \mathrm{C}$ on a reciprocal shaker. The amount of nigrifactin produced was measured at daily intervals according to the following method. The culture filtrate was rendered alkaline with $1 \mathrm{~N}$ $\mathrm{NaOH}$ and extracted with chloroform. The chloroform layer was extracted with $0.1 \mathrm{~N} \mathrm{HCl}$ and then modified Dragendorff's reagent ${ }^{4}$ ) was added to the acidic solution. Turbidity formed was expressed as $+, H, W$ and $\#$ scale. The mycelia were harvested

4) B. T. Cromwell and S. D. Rennie, Biochem. J., 58, 318 (1954). by filtration from the culture broth at various times during growth and then dried at $100^{\circ} \mathrm{C}$ for one hour and weighed.

Antimicrobial activity. Antimicrobial activities of the alkaloid were examined against Staphylococcus aureus 209 P, Escherichia coli, Candida albicans, Aspergillus niger and Penicillium chrysogenum Q 176 at the concentration of $650 \mathrm{ppm}$ according to the usual procedures.

Toxicity to mammals. The toxicity of the alkaloid to mammals was examined using mice by intraperitoneal administration. The alkaloid was diluted with water in series, if necessary. Groups of six dd-mice were used which were fed with a controlled diet for 3 days before the test.

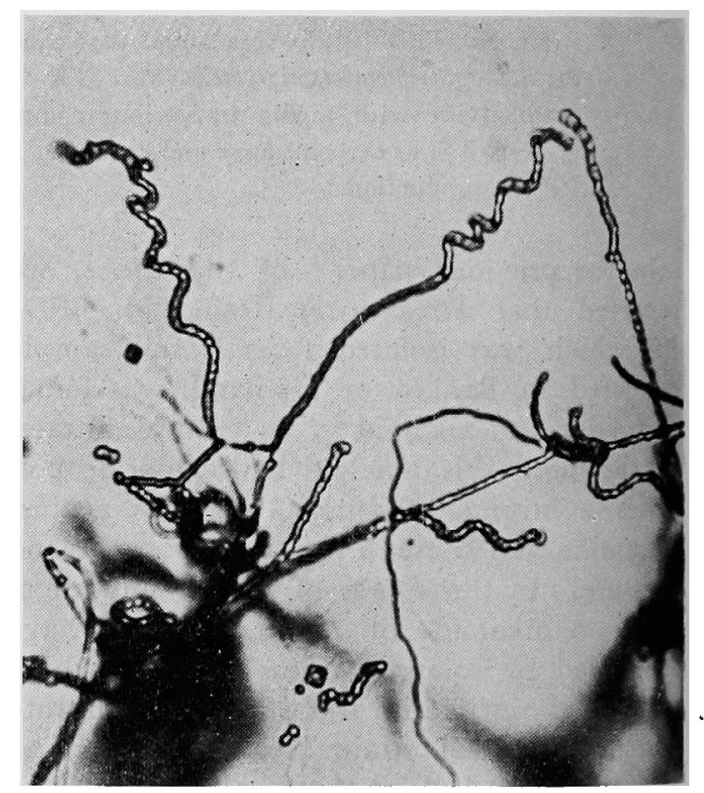

FIG. 1. Aerial Hyphae of Streptomyces Strain No. FFD-101 $(\times 600)$ (photomicrograph).

\section{RESULTS AND DISCUSSION}

\section{Taxonomical identification of Streptomyces strain No. FFD-101}

The sporophores are branched with tenden-' cy to curl and spirals (Fig. 1). The conidia are grown in chain of more than ten spores, 
Table II. Cultural Characteristics of Streptomyces Strain No. FFD-101

\begin{tabular}{|c|c|c|c|c|}
\hline Medium & & Growth & Aerial mycelium & Soluble pigment \\
\hline Glucose-Czapek & agar & good, dark brown & white to dark brown & brown \\
\hline Sucrose-Czapek & $"$ & scant, pinkish gray & white to gray & none \\
\hline Glucose-asparagine & " & good, cream-colored & gray & yellow \\
\hline Ca-malate & " & moderate, brownish & white & faint brown \\
\hline Tyrosine & " & moderate, white to pale brown & pale brown & dark brown \\
\hline Bennett's & " & good, bacteria-like, cream-colored & white & brown \\
\hline Nutrient & " & good, bacteria-like & none & brown \\
\hline Glucose peptone & " & good, bacteria-like, pale yellow & white & grayish brown \\
\hline Peptone-iron & " & good, pale yellow & none & dark brown \\
\hline Glucose-potato & " & good, white to pale brown & white & brown \\
\hline Bouillon broth & & $\begin{array}{l}\text { surface: moderate } \\
\text { bottom: palp-like growth }\end{array}$ & white & redish brown \\
\hline Gelatin stab $\left(18^{\circ} \mathrm{C}\right)$ & & good, white & white & brown \\
\hline Egg & & faint, whitish gray & none & darkish brown \\
\hline Carrot plug & & faint, pale yellowish brown & none & none \\
\hline Potato plug & & moderate, pale yellow, bacteria-like & none & dark brown \\
\hline Loeffler's serum & & scant, brownish & none & none \\
\hline
\end{tabular}

the shape of which are oval to elliptical, $0.6 \sim 0.7 \mu \times 0.4 \sim 0.5 \mu$, with smooth surface (Fig. 2).

The cultural and physiological characteristics of the strain is listed in Tables II and III. The utilization of carbon sources of the

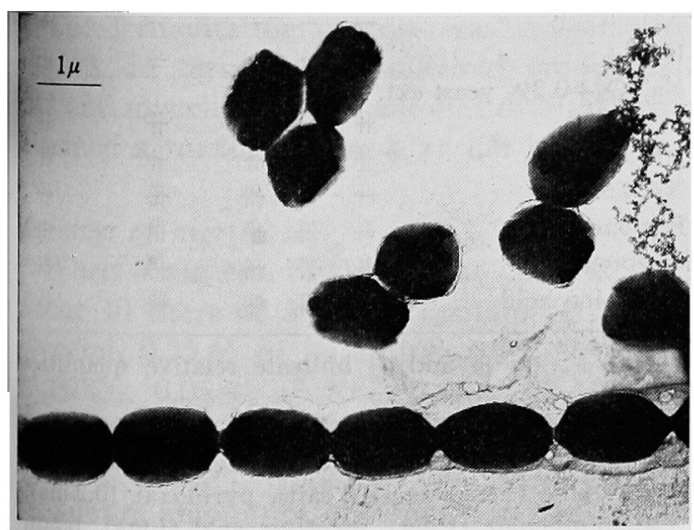

FIG. 2. Conidia of Streptomyces Strain No. FFD-101 (electronmicrograph). strain is shown in Table IV. From the results of these studies, the cultural and physiological characteristics of the strain No. FFD-101 are summarized as follows: Growth type on various organic media such as glucose peptone, nutrient, Bennett's and potato agar

TABle III. Biochemical and Physiological Properties of Streptomyces Strain No. FFD-101

\begin{tabular}{ll}
\hline $\begin{array}{l}\text { Melanin formation } \\
\text { Nitrate reduction }\end{array}$ & $\begin{array}{l}\text { positive } \\
\text { negative } \\
\text { Utilization of cellulose }\end{array}$ \\
$\begin{array}{l}\text { negative } \\
\text { positive (weak) }\end{array}$ \\
$\begin{array}{l}\text { Milk peptonization } \\
\text { Liquefaction of gelatin }\end{array}$ & $\begin{array}{l}\text { positive (weak) } \\
\text { positive }\end{array}$ \\
$\begin{array}{l}\text { Tyrosinase reaction } \\
\text { positive }\end{array}$ \\
$\begin{array}{l}\text { Hydrolysis of starch } \\
\text { growge for }\end{array}$ & positive (strong) \\
$\begin{array}{l}\text { Temperature for } \\
\text { growth (bouillon) }\end{array}$ & $22 \sim 42^{\circ} \mathrm{C}$ (opt. temp. $37^{\circ} \mathrm{C}$ ) \\
$\begin{array}{l}\text { Relation to oxygen } \\
\text { Thermal death point }\end{array}$ & $60^{\circ} \mathrm{C}$
\end{tabular}


Table IV. Utilization of Carbon Sources

\begin{tabular}{|c|c|}
\hline Carbon source & Utilization $^{a /}$ \\
\hline Arabinose & H \\
\hline Xylose & H \\
\hline Raffinose & H \\
\hline Rhamnose & $H$ \\
\hline Fructose & H \\
\hline Galactose & $H$ \\
\hline Mannose & $H$ \\
\hline Maltose & $H$ \\
\hline Lactose & $H$ \\
\hline Dextrin & $H$ \\
\hline Glycerol & $H$ \\
\hline Glucose & H \\
\hline Mannitol & $H$ \\
\hline Inositol & H \\
\hline Salicin & $H$ \\
\hline Sucrose & + \\
\hline Sorbitol & - \\
\hline Inulin & - \\
\hline
\end{tabular}

was bacteria-like accompanying no or little quantities of aerial hyphae. Color of aerial mycelium is white to gray or dark brown on synthetic media. Color of aerial mycelium is white and sometimes white to brown, soluble pigment is blackish brown (chromogenic) on various proteinous media. Melanoid pigment and tyrosinase reaction are positive. Among many species of Streptomyces described in "Bergey's Manual of Determinative Bacteriology," 7th Ed." and "The Actinomycetes," Vol. II," the strain No. FFD-101 appears to be most closely related to $S$. nigrifaciens from morphological properties, color of aerial mycelium on synthetic agar and some of physiological characteristics. However, in the following respects of morphological and physiological properties, the strain No. FFD-101 was found to be not com-

5) R. S. Breed, E. G. D. Murray and N. R. Smith, "Bergey's Manual of Determinative Bacteriology," 7th Ed., Williams and Wilkins Co., 1957.

6) S. A. Waksman, "The Actinomycetes," Vol. II, Williams and Wilkins Co., 1961. pletly identical with $S$. nigrifaciens described so far.

1) $S$. strain No. FFD-101 clearly forms spirals, although $S$. nigrifaciens did not.

2) $S$. strain No. FFD-101 exhibited strong starch hydrolysis, but $S$. nigrifaciens showed weak hydrolysis.

3) $\mathrm{NO}_{2}$ formation by $S$. strain No. FFD101 is negative, but that by $S$. nigrifaciens is positive.

4) S. strain No. FFD-101 utilizes many carbon sources as shown in Table IV.

Therefore $S$. strain No. FFD-101 should be assigned to a variant of $S$. nigrifaciens and designated as Streptomyces nigrifaciens var. FFD-101.

TABLe V. EFfect of Carbon and Nitrogen Sources on the Production OF THE ALKaLOID

\begin{tabular}{c} 
Time (hr) Max. value \\
\cline { 1 - 2 } $\begin{array}{c}\text { of the } \\
96 \quad 120144 \\
\text { alkaloid }\end{array}$
\end{tabular}

Carbon source

Soluble starch

Dextrin

Sucrose

Glycerol

Glucose

$\begin{array}{ccccc}H & H & H & H & H \\ H & H & H & H & H \\ H & H & H & H & + \\ H & H & H & \text { H } & H \\ H & H & H & H & t\end{array}$

Nitrogen source

$\mathrm{NaNO}_{3}+$ vitamine mix. ${ }^{a}$

\begin{tabular}{|c|c|c|c|c|c|c|}
\hline & & - & - & - & - & + \\
\hline $\mathrm{NH}_{4} \mathrm{NO}_{3}+$ & " & - & - & - & - & + \\
\hline Ureat+ & $\prime \prime$ & - & - & - & - & \pm \\
\hline \multicolumn{6}{|c|}{$\mathrm{NaNO}_{3}+0.2 \%$ yeast ext. } & H \\
\hline $\mathrm{NH}_{4} \mathrm{NO}_{3}+$ & " & $H$ & $H$ & $t$ & $H$ & H \\
\hline $\mathrm{NZ}$ amine & & $H$ & H & H & H & H \\
\hline Peptone & & $H$ & $H$ & H & H & \# \\
\hline Tryptone & & $H$ & $H$ & $H$ & $H$ & \# \\
\hline Casamino ac & & \# & \# & 册 & H⿻川 & H \\
\hline
\end{tabular}

$-,+, \#,+t$ and $H$ indicate relative quantities of precipitate formed.

a) Vitamine mixture: riboflavin $(2 \mathrm{mg})$, thiamine (1 $\mathrm{mg}$, as $\mathrm{HCl}$ salt), $p$-aminobenzonic acid ( $1 \mathrm{mg}$ ), pyridoxine ( $\mathrm{l} \mathrm{mg}$, as $\mathrm{HCl}$ salt), pyridoxal $(0.2 \mathrm{mg}$ ), Capantothenate (1 mg), nicotinic acid $(1 \mathrm{mg})$, biotin (10 ppm), folic acid (10 ppm), cyanocobalamin (1 ppm), inositol $(5 \mathrm{mg})$. 
Productivity of nigrifactin on various media

Effect of carbon source. Glycerol, glucose, sucrose, soluble starch and dextrin was added to the basal medium containing $0.35 \%$ casamino acid as nitrogen source to a concentration of $3 \%$. The yield of nigrifactin produced by shaking culture is shown in Table $\mathrm{V}$ A maximum production was obtained at $114 \mathrm{hr}$ with the medium containing $3 \%$ glycerol. Glucose, dextrin, sucrosose and soluble starch were inferior to glycerol for the production of nigrifactin.

Effect of nitrogen source. Various nitrogen sources including $\mathrm{NaNO}_{3}, \mathrm{NH}_{4} \mathrm{NO}_{3}$, urea, $\mathrm{NZ}$ amine, peptone and tryptone were added to the basal medium containing $3 \%$ glycerol as a carbon source to a concentration of $0.35 \%$. As represented in Table $V$. the organic nitrogen sources were generally better for the production of nigrifactin than the inorganic nitrogen. Particularly, casamino acid was the most suitable for its production. $\mathrm{NZ}$ amine and peptone were somewhat inferior. With the inorganic nitrogen sources, no measurable amount of nigrifactin was produced. However, when $0.2 \%$ yeast extract was added to the medium containing inorganic nitrogen, considerable amount of nigrifactin was obtained.

\section{Fermentation process}

The fermentation process was revealed in Fig. 3, in terms of the alkaloid production, $\mathrm{pH}$ and mycelium. The amount of nigrifactin attained a maximum peak at $120 \mathrm{hr}$.

\section{Isolation of nigrifactin}

When strain No. FFD-101 was cultivated in about 10 liters of medium containing $3 \%$ of glycerol, $0.35 \%$ of casamino acid, $0.1 \%$ of $\mathrm{K}_{2} \mathrm{HPO}_{4}, 0.05 \%$ of $\mathrm{KCl}, 0.05 \%$ of $\mathrm{MgSO}_{4}$. $7 \mathrm{H}_{2} \mathrm{O}, 0.001 \%$ of $\mathrm{FeSO}_{4} \cdot 7 \mathrm{H}_{2} \mathrm{O}$ at $30^{\circ} \mathrm{C}$ for 5 days by jar fermentor, it accumulated maximum amount of nigrifactin in the culture fluid.

A schematic outline of isolation procedure

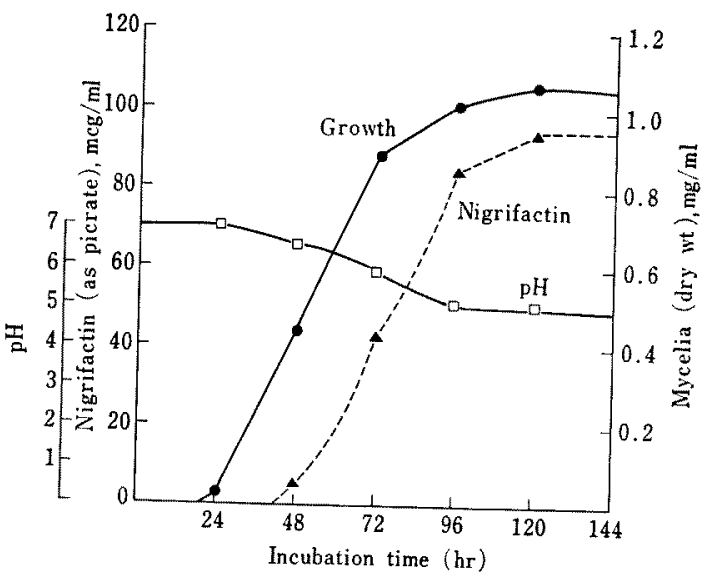

FIG. 3. Fermentation Process of Nigrifactin in a Jar Fermentor.

Cultural condition: aeration rate 1 vvm, agitation $300 \mathrm{rpm}$ seed $3 \%$, incubation temperature $30^{\circ} \mathrm{C}$.

Medium: glycerol $3 \%$, casamino acid 0.35 , $\mathrm{K}_{2} \mathrm{HPO}_{4} 0.1, \mathrm{KCl} \mathrm{0.05}, \mathrm{MgSO}_{4} \cdot 7 \mathrm{H}_{2} \mathrm{O} 0.05, \mathrm{FeSO}_{4}$. $7 \mathrm{H}_{2} \mathrm{O} 0.001, \mathrm{pH} 7.0$.

Symbols:

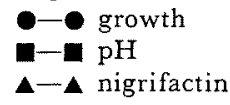

is shown in Fig. 4. The broth (about 10 liters, $\mathrm{pH}$ 5.0) was filtered, concentrated in vacuo to 2 liters under the inert gas and was treated at $\mathrm{pH} 4.0$ twice with an equal volume of ethyl acetate each time to remove yellow pigment, acidic and neutral materials and lipids. The aqueous layer was then adjusted to $\mathrm{pH} 10$ with $1 \mathrm{~N} \mathrm{NaOH}$ and extracted three times with an equal volume of $n$-hexane each time. The combined $n$-hexane layer was washed with water to eliminate yellow pigment. Thereafter the $n$-hexane layer was extracted three times with $200 \mathrm{ml}$ portions of $0.1 \mathrm{~N} \mathrm{HCl}$. The aqueous solution was again made alkaline and the above extraction procedure was repeated to give $150 \mathrm{ml}$ of $0.1 \mathrm{~N} \mathrm{HCl}$ extract of nigrifactin.

As the free alkaloid was very labile and easily oxidized to a brown syrup when standing even under the inert gas, it could not be obtained in a crystalline state. In order to get the alkaloid in a pure state, it 


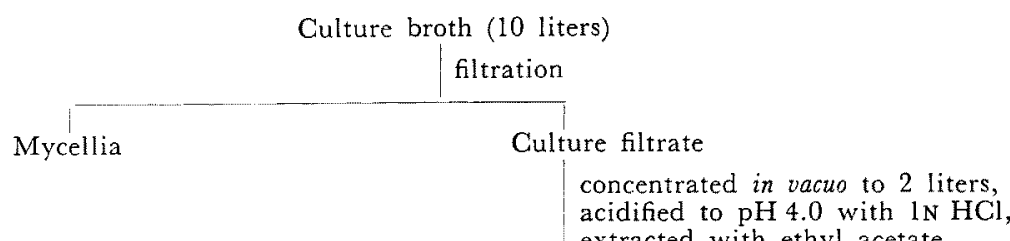
acidified to $\mathrm{pH} 4.0$ with $1 \mathrm{~N} \mathrm{HCl}$
extracted with ethyl acetate

Ethyl acetate phase Aqueous phase

made alkaline to $\mathrm{pH} 10$ with $1 \mathrm{~N} \mathrm{NaOH}$, extracted with $n$-hexane

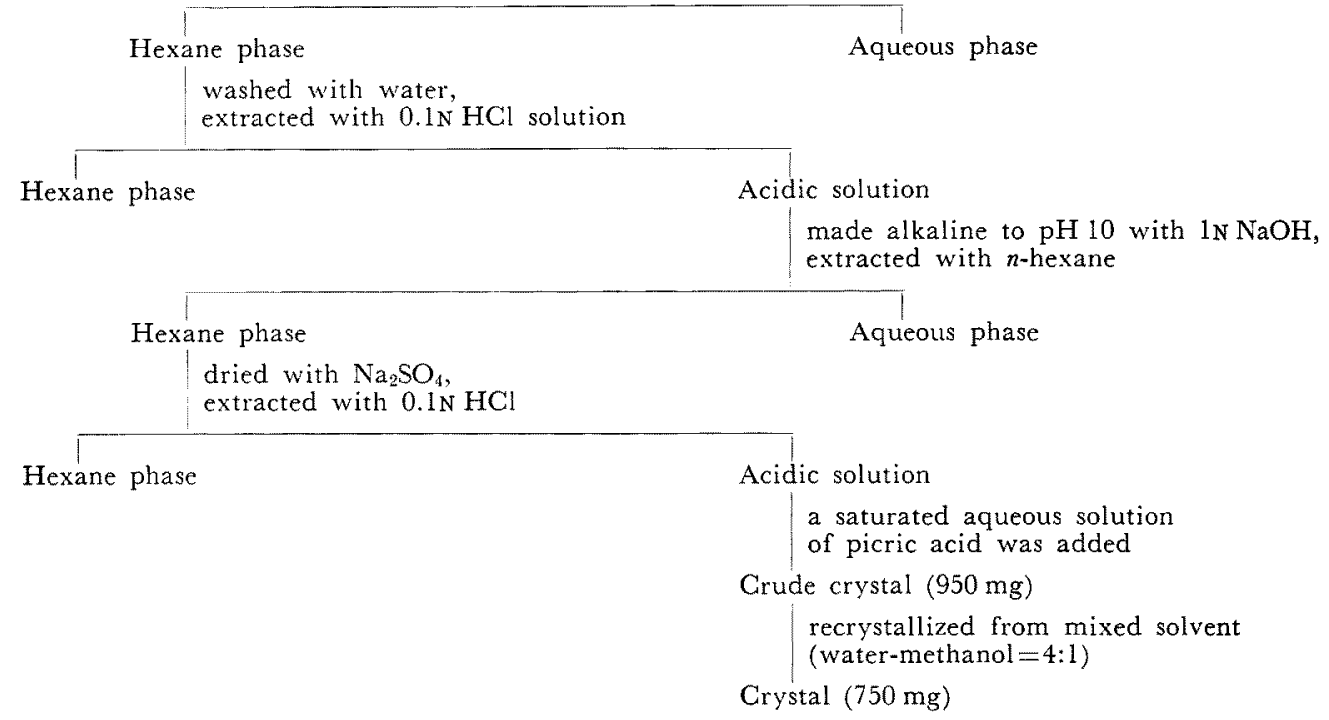

FIG. 4. Isolation Procedure of Nigrifactin.

could not be obtained in a crystalline state. In order to get the alkaloid in a pure state, it was converted into its crystalline salts of organic acids, such as picric, oxalic and flavianic acids. A saturated aqueous solution of picric acid was added dropwise to the above mentioned acidic solution of the alkaloid until no more precipitate was formed. The crude picrate $(950 \mathrm{mg}$ ) thus obtained was recrystallized several times from mixed solvent of water-methanol $(4: 1)$ to afford $750 \mathrm{mg}$ of lemon-yellow needles. The picrate melts at $175.5 \sim 176^{\circ} \mathrm{C}$ under decomposition. In preliminary experiments, various kinds of solvents systems and carriers were tested. Since two solvent system, i.e., butanol: acetic acid: water ( $4: 1: 1, R f=0.43$ ), acetone: methanol $(9: 1, R f=0.27)$ on Kiesel gel $\mathrm{G}$ plate and three solvent system, i.e., butanol: acetic acid: water $(4: 1: 1, R f=0.93)$, cyclohexane: chloroform: methanol $(15: 15: 1, R f=0.87)$, isopropanol: $5 \%$ ammonia $(10: 1, R f=0.81)$ on aluminium oxide $G$ (Merk) plate gave the most satisfactory results, they were used for confirmation of purity of the alkaloid. The picrate is soluble in methanol, chloroform, ethanol, acetone and dimethyl sulfoxide. It is slightly soluble in $0.1 \mathrm{~N} \mathrm{NaOH}$ and insoluble in hexane, benzene and ether.

Pharmacological activity of nigrifactin

The effect of nigrifactin on blood pressure 


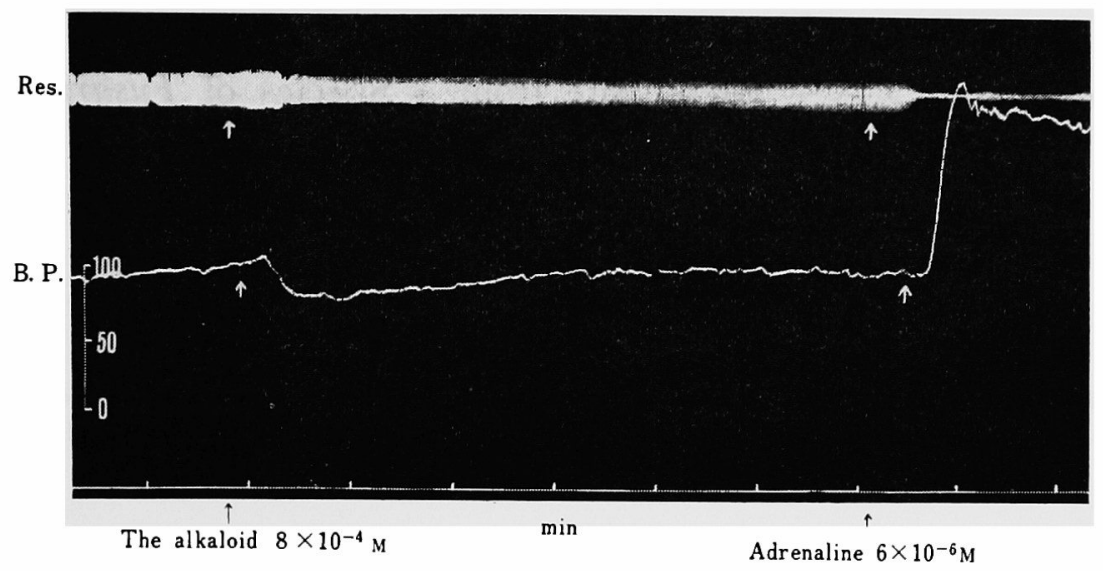

FIG. 5. Effect of Nigrifactin on the Blood Pressure of Anaesthetized Rabbit.

Res.: Respiration

B.P.: Blood pressure

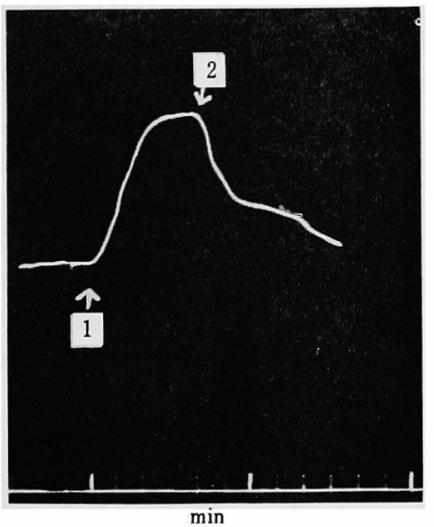

FIG. 6. Antihistamic Activity of Nigrifactin by Magnus Method with Isolated Guinea Pig Intestine.

1: Histamine $6 \times 10^{-6} \mathrm{M}$

2: The alkaloid $8 \times 10^{-4} \mathrm{M}$

are shown in Fig. 5. Intravenous injection of $6 \mathrm{mg} / \mathrm{kg}$ of nigrifactin caused a transient fall of blood pressure of rabbit, but did not antagonize against the response of $0.2 \mathrm{mg} / \mathrm{kg}$ of adrenaline.

The inhibition of histamine response $\left(6 \times 10^{-6} \mathrm{M}\right)$ by nigrifactin $\left(8 \times 10^{-4} \mathrm{M}\right)$ was about $60 \%$ (Fig. 6). Nigrifactin $\left(8 \times 10^{-4} \mathrm{M}\right)$ inhibited about $20 \sim 25 \%$ of choline response $\left(5 \times 10^{-5} \mathrm{M}\right)$, but did not antagonize against other stimulants, i.e., atropine, adrenaline and nor-adrenaline.

\section{Toxicity to mammals}

It was little toxic to mice showing no significant symptom by intraperitoneal injection of $195 \mathrm{mg} / \mathrm{kg}$ doses.

\section{Antimicrobial activity}

The alkaloid was not effective against five test organisms, i.e., Staphylococcus aureus $209 \mathrm{P}$, Escherichia coli, Candida albicans, Aspergillus niger and Penicillium chrysogenum $Q 176$ at the concentration of $650 \mathrm{ppm}$.

Acknowledgement. The authors thanks Dr. S. Doi, Dr. T. Goto, Dr. K. Wada and Mr. N. Kato for their helpful advice and discussions. They also dedicate their thanks to researchers in Laboratory of Fermentation Chemistry, Nagoya University for their helpful advice. 